\title{
Diplycosia papuana (Ericaceae: Vaccinioideae: Gaultherieae): a new endemic species from central New Guinea
}

\author{
Wendy A. Mustaqim ${ }^{1}$, Timothy M. A. Utteridge ${ }^{2}$ (I) \& Charlie D. Heatubun ${ }^{2,3,4}$
}

Summary. Diplycosia papuana (Ericaceae: Vaccinioideae: Gaultherieae), a new endemic species from central New Guinea, is described and illustrated here. Notes on the distribution, ecology and conservation status of the new species, as well as a consideration of closely related species, are provided.

Key Words. Indonesia, Irian Jaya, Malesia, Papua, taxonomy.

\section{Introduction}

Diplycosia Blume is one of the more poorly known genera of Ericaceae in Malesia. This is true especially in New Guinea, where several species are awaiting description. During the early stage of a revision of New Guinean Diplycosia, carried out as part of an MSc project by the first author, an unidentified specimen of this genus deposited in Herbarium Bogoriense (BO) was found. This specimen was collected by the French ecologist Jean-Marie Mangen during her vegetation study in Mount Trikora (Mangen 1993). Comparison with other species, and critical examination of the pertinent literature, including Hermann Otto Sleumer's monographic work treating the Ericaceae of New Guinea (Sleumer 1942, 1957, 1961, 1963, 1964, 1967) and notes from Takeuchi (2007), was undertaken and the specimen did not match any previously described species. We also have studied all existing type specimens of New Guinean Diplycosia but none of them were found to be similar and, hence, we conclude that Mangen's collection is an undescribed species.

Diplycosia is strongly supported as monophyletic in molecular studies (Fritsch et al. 2011). It has several putative synapomorphies, including entire leaf margins, fasciculate inflorescences, terminal anther tubules (Sleumer 1967), and a base chromosome number of $\mathrm{x}=18$ (Argent \& Brunton 1984; Middleton \& Wilcock 1990). Note, however, that the most appropriate name for the genus may change after further systematic research, depending on the circumscription of the genus Gaultheria Kalm ex L. (Fritsch et al. 2011), which could be treated either as a very large genus or as a much smaller one with several related genera; we continue to use Diplycosia as currently circumscribed.

\section{Taxonomic Treatment}

Diplycosia papuana Mustaqim, Utteridge E Heatubun sp. nov. Type: Indonesia, Papua Province (Irian Jaya), Yahukimo Regency, Valentijn Mts, limestone ridge north of Angguruk, east-west orientated [ $4^{\circ} 15^{\prime} \mathrm{S}$ $139^{\circ} 25^{\prime} \mathrm{E}$ ], 1,530 m, J.-M. Mangen 2194 (holotype $\mathrm{BO}$ !; isotypes A, E, L, LUX).

http:/ /www.ipni.org/urn:lsid:ipni.org:names:77202808-1

Epiphytic shrubs. Twigs terete, slender, c. $2 \mathrm{~mm}$ diam. at the apex, with a few longitudinal fissures on the flowering parts, indumentum of subpatent bristles, varying in length, up to $3.25 \mathrm{~mm}$ long, base slightly thickened, blackish, persistent, fine hairs absent. Leaves rather densely arranged, circular, $1.2-1.8 \times$ $1.2-2.0 \mathrm{~cm}$, length per width $0.9-1(-1.11)$ times, coriaceous, apex rounded, rarely obtuse, apical gland protruding at $0.5-0.6 \mathrm{~mm}$ from the edge of leaf apex, margin crenulate, revolute, teeth spaced $1.25-2 \mathrm{~mm}$ apart, marginal hairs setose, rather persistent, base broadly rounded; adaxial surface of lamina with subpatent bristles, persistent, abaxial surface clad with subpatent and persistent bristles, these not distinctly

\footnotetext{
Accepted for publication 7 November 2019. Published online 20 December 2019

1 Program Studi Biologi Tumbuhan, Departemen Biologi, Fakultas Matematika dan IImu Pengetahuan Alam, Institut Pertanian Bogor, Bogor, Jawa Barat, 16680, Indonesia.

2 Royal Botanic Gardens, Kew, Richmond, Surrey, TW9 3AB, UK. e-mail: t.utteridge@kew.org

3 Badan Penelitian dan Pengembangan Daerah Provinsi Papua Barat, J.. Brig. Jend. Mar. (Purn.) Abraham O. Atururi, Arfai, Manokwari, 98315, Indonesia.

${ }^{4}$ Fakultas Kehutanan, Universitas Papua, Jl. Gunung Salju, Amban, Manokwari, Papua Barat, 98314, Indonesia.
} 
thickened at the blackish base; midrib impressed above, slightly raised below, gradually narrowing to apex; 3 (-5)-plinerved, lateral pairs 1 (-2) on each side of the midrib, slightly or obscurely immersed above, curved to the apex, lowest basal nerves from the base of the lamina, reaching about half of the lamina or sometimes obscure, lowest suprabasal arising at $1-2 \mathrm{~mm}$ from the lamina base, curving from a rather straight base, usually reaching the apex and anastomosing near the base of apical gland, rarely disappearing toward distal end, higher-order nerves inconspicuous. Petiole subterete, upper surface flat, $1.5-3.25 \times 1.25 \mathrm{~mm}$, adaxial groove shallow, both sides with subappressed bristles, bristles blackish and slightly thickened at the base. Inflorescence axillary, 3flowered. Pedicels curving, rather slender, $7 \times 0.5 \mathrm{~mm}$, smooth, covered with subappressed to subpatent bristles, hairs $1-1.25 \mathrm{~mm}$ long, base not thickened, blackish, persistent. Basal bracts ovate, c. $1.25 \mathrm{~mm}$ long, glabrous dorsally, margin fimbriate; apical bracteoles ovate, $1.25 \mathrm{~mm}$ long, obtuse, outside with few appressed bristles, glabrous inside, margin fimbriate. Flowers 4 - 5-merous. Calyx tube turbinate, c. $1 \mathrm{~mm}$ long, rugulose, glabrous; lobes ovate-triangular, c. $2 \times$ $2 \mathrm{~mm}$, rugulose, apex obtuse to almost rounded, glabrous outside, margin fimbriate. Corolla urceolate, c. $3.5 \mathrm{~mm}$ long from the base of the tube to the apex of lobes (after rehydration), tube $2.5 \times 2 \mathrm{~mm}$, glabrous on both surfaces; lobes ovate-triangular, c. $1 \mathrm{~mm}$ long, $1.25 \mathrm{~mm}$ wide at the base, apex acute, glabrous on both surfaces. Stamens 8 or 10 , filaments linear, c. $1.5 \mathrm{~mm}$ long, slightly dilated at the base, S-shaped, glabrous, anthers ovate-oblong, c. $1.4 \mathrm{~mm}$ long including the short apical tubules, granular, base with patent and blunt apiculus. Ovary shallowly lobed, glabrous. Nectary of 8 or 10 free lobes, twice the number of perianth segments, appressed to the ovary, oblong, c. $0.4 \times 0.15 \mathrm{~mm}$, blunt at apex. Style cylindrical, c. $3 \times 0.2 \mathrm{~mm}$, glabrous. Fruit not seen. Fig 1.

RECOGNITION. Plant exclusively bristly, the twigs without a fine short indumentum of hairs. Similar to Diplycosia varians Sleumer in having 4 - 5-merous flowers, but differing in the exclusively circular leaves and in its smaller flowers (calyx tube c. $1 \mathrm{~mm}$ vs 4 $7 \mathrm{~mm}$ long, corolla c. $3.5 \mathrm{~mm}$ vs $8-9 \mathrm{~mm}$ long, filaments c. $1.5 \mathrm{~mm}$ vs $5 \mathrm{~mm}$ long and anthers c. $1.4 \mathrm{~mm}$ vs $2.8 \mathrm{~mm}$ long in D. varians).

DISTRIBUTION. Indonesia: Papua Province, Central Ranges (Valentijn Mts), Yahukimo Regency. Only known from the type locality (Map 1).

HABITAT. Montane forest, on a limestone ridge; alt. $1,530 \mathrm{~m}$.

CONSERVATION Status. Data Deficient (IUCN 2012). Recent data on the population size or label information are unavailable. Being a component of montane forest, however, this species may become susceptible to climate change in the future; this is one of most prominent environmental stresses in the tropical montane ecosystem (Raxworthy et al. 2008), as has been highlighted for the New Guinea highlands (Hope 2014). Further field research is required to provide adequate data to allow an adequate assessment.

PHENOLOGY. Collected in flower in February.

ETYMOLOGY. The epithet refers to the name of the type locality in Papua Province, the current geographical name of the Indonesian part of New Guinea.

VERNACULAR NAME. None known.

USES. None known.

NOTES. The floral parts are $4-5$-merous and, in accordance with the 'usual rule' for the genus (Argent 2014), the number of stamens should be twice the number of perianth parts (i.e. calyx or corolla lobes), thus there will be 8 stamens in a 4-merous flowers and 10 in a 5-merous flower. In Diplycosia papuana, complete 4merous flowers (with stamens present within the corolla) are available, but only a single 5-merous flower bearing five calyx lobes and with the corolla and stamens fallen off is included in the specimen. From this observation, we conclude that the number of floral parts ranges from 4- to 5-merous in this species. On the basis of this character, the species is close to $D$. varians, a species from the eastern part of New Guinea. However, the length of the corolla in $D$. varians is $8-9 \mathrm{~mm}$ in the dry state (reaching $10-11 \mathrm{~mm}$ when fresh), which is distinctly larger than that for D. papuana (corolla only c. $3.5 \mathrm{~mm}$ long).

In addition, Sleumer (1967) used orbicular leaves in his key to lead to Diplycosia varians, but this appears to be erroneous as no such characters are mentioned in the description made by him in that account or in the protologue (Sleumer 1964). Further examination of the type of D. varians (Vink 16007), shows that the lowest length per width index was just 1.14 for one leaf (note, however, that the apex of this leaf is damaged, and this has no doubt reduced both the length of this leaf and its length per width index) but was usually $1.34-1.41$, compared to up to $0.9-1(-1.11)$ in D. papuana. Although intermediates may be revealed in future collections, the predominant leaf shape is clearly different between the two species. Therefore, the circular leaf shape (supported by the relatively low length per width index), serves as a diagnostic character of D. papuana.

Furthermore, 4-merous flowers in Diplycosia are rare not only in New Guinea but also throughout the genus. Only a few Diplycosia species are known to possess this character (Sleumer 1967; Argent 2014), which has been used as an exclusive character of a species. Just one Diplycosia species, D. kemulensis J.J.Sm., has been recorded to date with only 4-merous flowers; the presence of both 4-merous flowers and 5-merous 


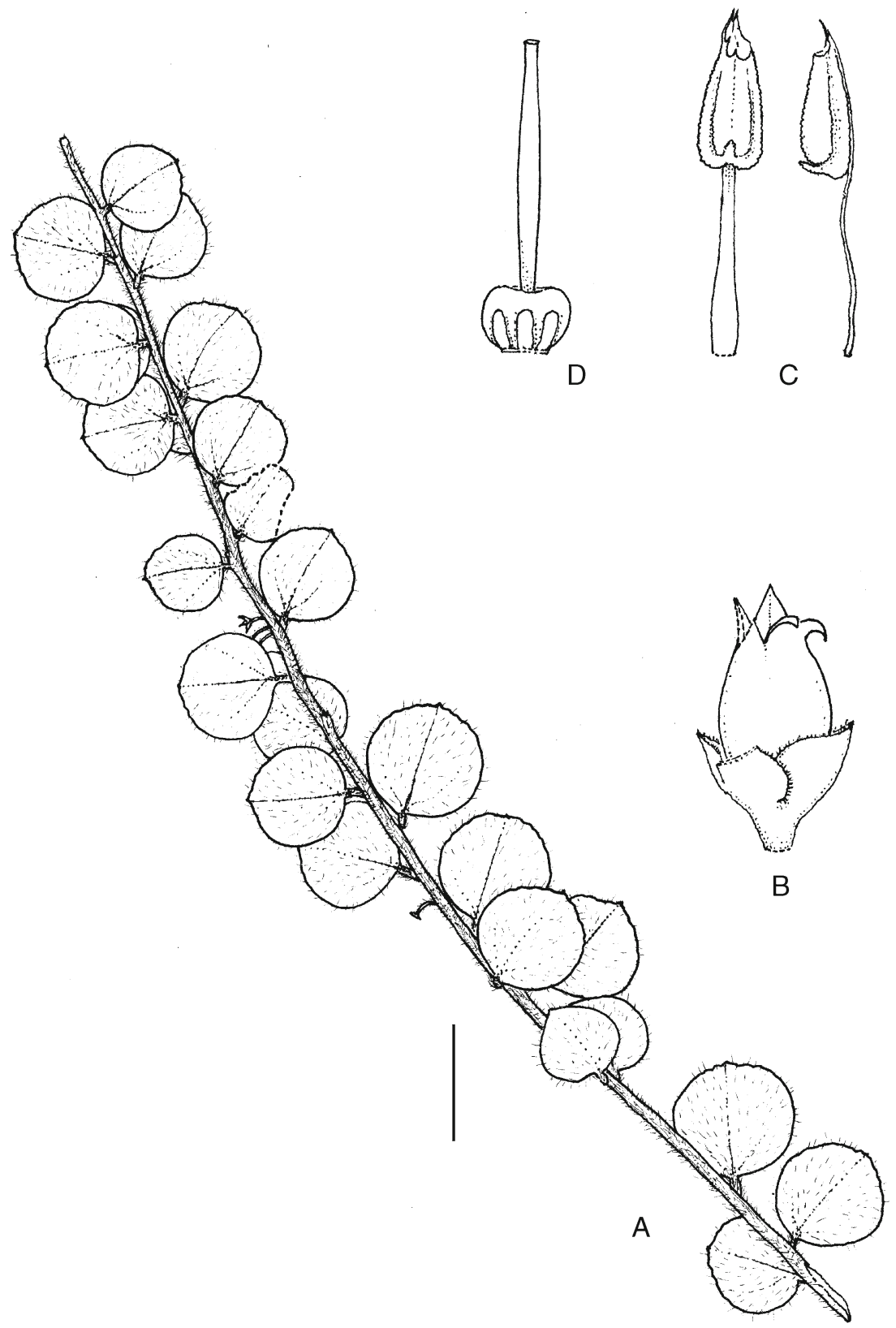

Fig. 1. Diplycosia papuana. A twig; B flower; C stamen, front and side views; D ovary and style. Scalebar A 2 cm; B 2.2 mm; C 1.1 $\mathrm{mm} ; \mathrm{D} 1.5 \mathrm{~mm}$. DRAWN BY WENDY A. MUSTAQIM.

flowers is more common and has been recorded in D. lancifolia Ridl., D. parvifolia Merr., D. stenophylla Sleumer and D. tetramera Sleumer.

Diplycosia papuana belongs to the group of seven species of New Guinea Diplycosia with small flowers with the corolla usually c. $4 \mathrm{~mm}$ long (or shorter), the others being: D. soror Becc. (corolla length: $3.5 \mathrm{~mm}$ ), D. subglobularis Sleumer (2 mm), D. pendens Sleumer (3 $\mathrm{mm})$, D. morobeensis Sleumer $(4 \mathrm{~mm})$, D. schramii Sleumer (c. $4 \mathrm{~mm}$ ), and the most similar D. setiloba Sleumer $(4-5 \mathrm{~mm})$. Exclusively or predominantly subcircular to rounded leaves can be found in some other Diplycosia species, namely D. crenulata Sleumer,
B
D. rubidiflora J.J.Sm., D. undata J.J.Sm. and D. scabrida Becc. All of these species are distributed outside New Guinea, and given the very local distributions of most species of Diplycosia, they are unlikely to be conspecific. Compared to other members of the genus in New Guinea, the new species described here appears to be similar to D. muscicola Sleumer and D. rosea Sleumer in having rather slender and not rigid branches, but the leaves of these two species are predominantly elliptic in shape. Phylogenetic work is needed to understand whether these are monophyletic groups and, if so, the position and relationships of D. papuana within the genus. 


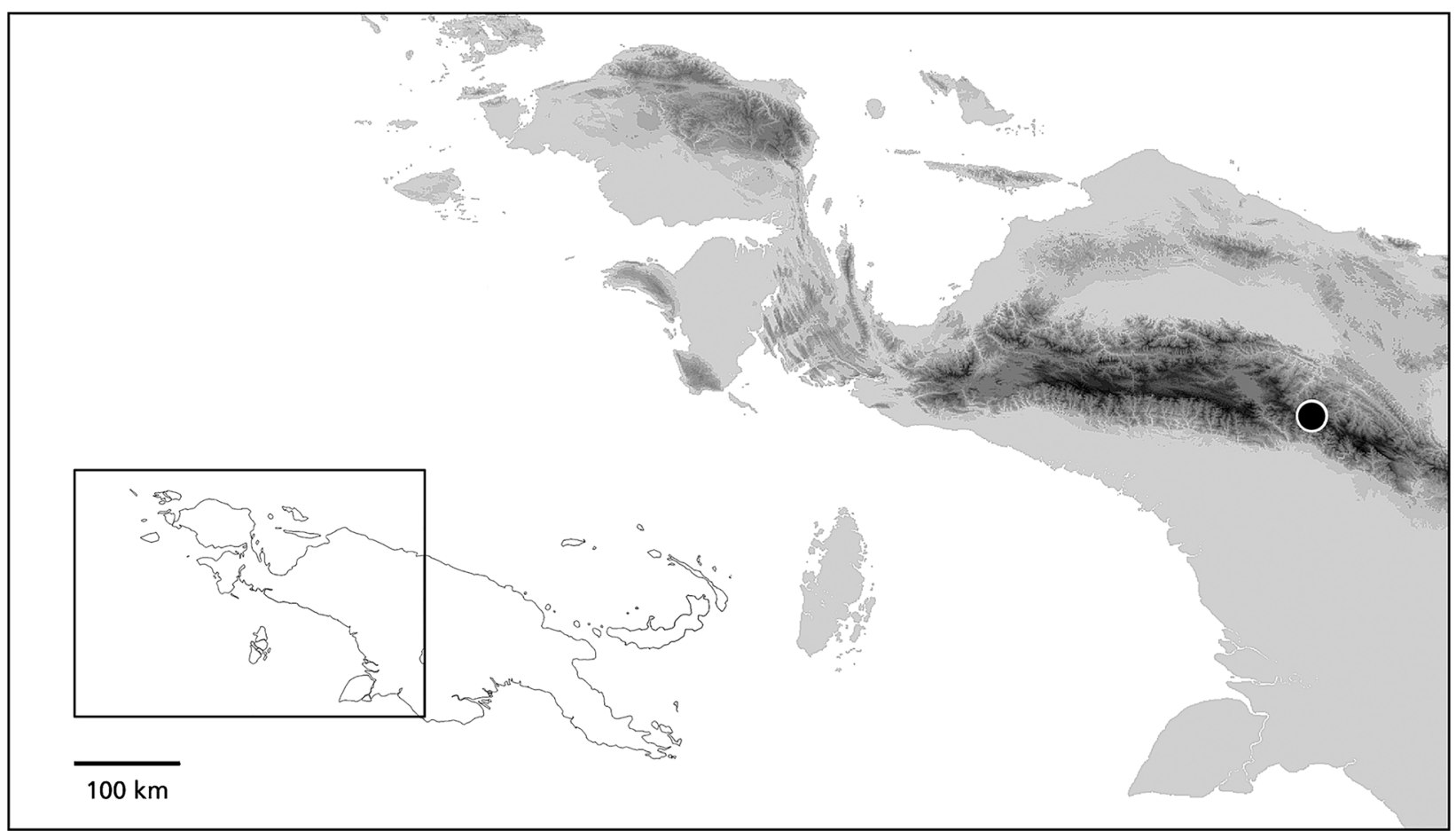

Map 1. Distribution of Diplycosia papuana.

Taxonomic information on Diplycosia in the central part of New Guinea is scarce, especially for the central cordillera mountains such as the Jayawijaya to Star Mountains. Some species recorded from this area are known only from very limited collections; for example, D. stellaris Sleumer and D. subglobularis Sleumer are each known from a single locality and from a single collection from Mount Antares in the easternmost part of Papua Province (Sleumer 1967). Some collections made after Sleumer's work in the region have resulted in range extensions for some species previously thought to have restricted distributions. For example, D. lamii J.J.Sm. (Mustaqim et al. in prep.) is previously only known from Mount Doorman (Lam $1605,1791,1808)$ but further exploration revealed that this species also occurs in the Lake Habbema area (Argent $\mathcal{E}$ Mendum 92560, Argent E Tanjung 92343).

\section{Determination of Diplycosia papuana}

Using Sleumer's key in the Flora Malesiana account (Sleumer 1967), this new species would key out as Diplycosia luzonica (A.Gray) Merr. \& H.F.Copel., a species from the Philippines. Diplycosia luzonica, however, possesses an acuminate leaf apex (vs obtuse or rounded), does not have 4-merous flowers (vs 4-5-merous), has filaments $2-3 \mathrm{~mm}$ long (vs c. $1.5 \mathrm{~mm}$ ) and has anthers c. $2 \mathrm{~mm}$ long (vs c. 1.4 $\mathrm{mm}$ ). In order to facilitate determination of Diplycosia papuana, a modification of Sleumer's key (Sleumer 1967), adapted into a parallel style, is presented here:

61. Leaves rigidly coriaceous, \pm concave when $d r y \ldots \ldots \ldots \ldots \ldots \ldots \ldots \ldots \ldots \ldots \ldots \ldots \ldots \ldots \ldots$

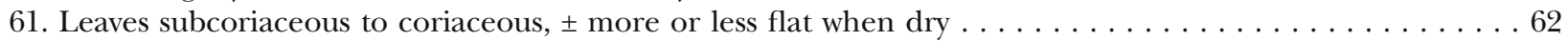

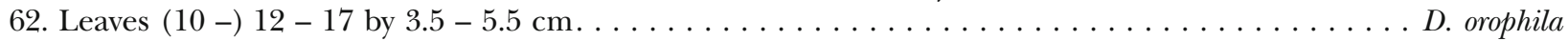

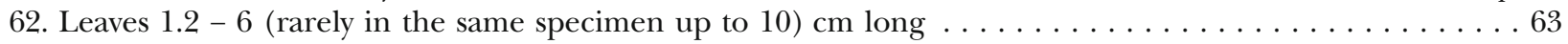

63. Filaments $1.5 \mathrm{~mm}$ long. Leaf blades up to $1.8 \mathrm{~cm}$ long, broadly obtuse or rounded at apex.... D. papuana

63. Filaments $2-3 \mathrm{~mm}$ long. Leaf blades usually $3 \mathrm{~cm}$ or longer, acuminate or rarely obtuse ..... D. luzonica

\section{Acknowledgements}

The first author thanks the Head of Botany Division, Herbarium Bogoriense, Research Center for Biology Indonesia Institute of Sciences, for allowing the access to specimens, and Mrs Tutie Djarwaningsih for assistance during his work in BO. We are deeply indebted to George Argent who critically read the early description and diagnosis of the species. Also to Mrs Tatik Chikmawati for supervisory suggestions and help during the master's study in Institut Pertanian Bogor.

Open Access This article is distributed under the terms of the Creative Commons Attribution 4.0 International License (http://creativecommons.org/ 
licenses/by/4.0/), which permits unrestricted use, distribution, and reproduction in any medium, provided you give appropriate credit to the original author(s) and the source, provide a link to the Creative Commons license, and indicate if changes were made.

\section{References}

Argent, G. (2014). A contribution to the study of the genus Diplycosia (Ericaceae) in Sulawesi, Indonesia. Edinburgh J. Bot. 71(1): 83 - 115.

\& Brunton, D. (1984). Some chromosome numbers in the Ericaceae. Notes Roy. Bot. Gard. Edinburgh 11: 561 - 564.

Fritsch, P. W., Lu, L., Bush, C. M., Cruz, B. C., Kron, K. A. \& Li, D.-Z. (2011). Phylogenetic analysis of the wintergreen group (Ericaceae) based on six genic regions. Syst. Bot. 36: $990-1003$.

Hope, G. (2014). The sensitivity of the high mountain ecosystems of New Guinea to climatic change and anthropogenic impact. Arct. Antarct. Alp. Res. 46(4): $777-786$.

International Union for Conservation of Nature (2012). IUCN Red List Categories and Criteria: Version 3.1, Second edition. IUCN, Gland \& Cambridge.

Mangen, J.-M. (1993). Ecology and Vegetation of Mt Trikora, New Guinea (Irian Jaya/Indonesia). Museum d'Histoire Naturelle de Luxembourg, Luxemburg.

Middleton, D. J. \& Wilcock, C. C. (1990). Chromosome counts in Gaultheria and related genera. Edinburgh J. Bot. 47: 303 - 313.
Raxworthy, C. J., Pearson, R. G., Rabibisoa, N., Rakontodrazafy, A. M., Ramanamanjato, J.-B., Raselimanana, A. P., Wu, S., Nussbaum, R. A. \& Stone, D. A. (2008). Extinction vulnerability of tropical montane endemism from warming and upslope displacement: a preliminary appraisal for the highest massif in Madagascar. Global Change Biol. 14: 1703 - 1720.

Sleumer, H. (1942). Revision der Ericaceen von NeuGuinea 2. Bot. Jahrb. Syst. 72: $207-269$.

(1957). Florae Malesianae precursores XIV: a revision of the genus Diplycosia (Ericaceae). Reinwardtia 4: 119 - 161.

(1961). Florae Malesianae precursores XXVII: supplementary notes on Malaysian Ericaceae (Gaultheria, Costera, Diplycosia). Blumea 11: 1 - 8. (1963). Florae Malesianae precursores XXXV: supplementary notes towards the knowledge of the Ericaceae in Malaysia. Blumea 12: 89 - 144.

(1964). Florae Malesianae precursores XXXIX: supplementary notes towards the knowledge of the Ericaceae in Malesia II. Blumea 12: 339 - 347.

(1967). Ericaceae. Fl. Males. 1 6(5): 669 - 914.

Takeuchi, W. (2007). Some notes on Ericaceae from recent expeditions to New Guinea summit environments. Harvard Pap. Bot. 12: 163 - 171.

\section{Publisher's Note}

Springer Nature remains neutral with regard to jurisdictional claims in published maps and institutional affiliations. 